\author{
(online) $=$ ISSN $2285-3642$ \\ ISSN-L = $2285-3642$ \\ Journal of Economic Development, Environment and People \\ Volume 8, Issue 1, 2019 \\ URL: http://jedep.spiruharet.ro \\ e-mail: office jedep@spiruharet.ro
}

\title{
Short Term Portfolio Investment and BI Rate: Do They Determine the Stabilization of Rupiah Exchange Rate in Indonesia?
}

\author{
Chenny Seftarita ${ }^{1}$, Fitriyani ${ }^{2}$, Cut Zakia Rizki ${ }^{3}$, Diana Sapha ${ }^{4}$, and Abd. Jamal ${ }^{5}$ \\ 1,2,3,4,5 Development Economics Department, Faculty of Economics and Business, \\ Universitas Syiah Kuala, Aceh, Indonesia
}

\begin{abstract}
This study aims to investigate the influence of short-term portfolio investments and $\mathrm{BI}$ interest rate on fluctuation of rupiah exchange rate in Indonesia. The data used is quarterly data from 2010 to 2016 collected from Indonesia Central Bank. Using the Autoregressive Distributed Lag (ARDL) method, the result showed that rupiah exchange rate was strongly influenced by shocks in the private debt securities, joint stock price index, and BI Rate, both in the long run and short run. Moreover, it is found that there was a short-run and long-run balance relationship between Short Term Portfolio Investments and $\mathrm{BI}$ rate against the rupiah exchange rate. Thus, it is recommended that in order to stabilize the exchange rate, it is necessary to maintain the stability of short-term portfolio investments.
\end{abstract}

Keywords: Short Term Portfolio Investments, Nominal Exchange Rate, BI Rate, ARDL

JEL Codes: C32, E42, G11

How to cite: Seftarita, C., Fitriyani, F., Rizki, C., Sapha, D., \& Jamal, A. (2019). Short Term Portfolio Investment and BI Rate: Do They Determine the Stabilization of Rupiah Exchange Rate in Indonesia?. Journal of Economic Development, Environment and People, 8(1), 18-28. doi:http://dx.doi.org/10.26458/jedep.v8i1.608

\section{Introduction}

Volatility in the exchange rate has severely happened in Indonesia in the last few years after the global crisis in 2008. As an open economy country, Indonesia faces a problem regarding the weakening of the exchange rate. Rupiah exchange rate against the US Dollar continued to depreciate and reached its peak in 2018, where the rupiah was Rp15,329 per US dollar, shown in Figure 1.

\footnotetext{
${ }^{*}$ Corresponding Author. Tel/Mobile Phone: +62 8113152231;

Email address: fitriyani@unsyiah.ac.id
} 


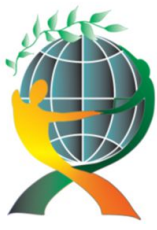

\author{
(online) $=$ ISSN $2285-3642$ \\ ISSN-L = $2285-3642$ \\ Journal of Economic Development, Environment and People \\ Volume 8, Issue 1, 2019
}

URL: http://jedep.spiruharet.ro

e-mail: office jedep@spiruharet.ro

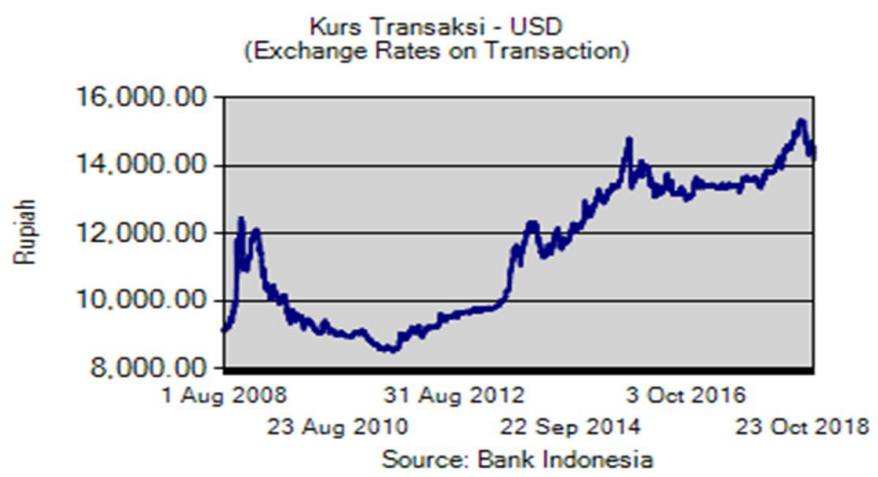

Source: (Bank Indonesia, 2018)

Figure 1. Rupiah Exchange Rate (IDR/USD) Fluctuation from 2008 to 2018

Some of the factors expected to affect the exchange rate include short-term portfolios investment such as debt securities and shares. Change in private debt was expected to affect the exchange rate fluctuation. Moreover, "Hot money", was also prone to cause the changes in the rupiah exchange rate, particularly when there was a significant decline in the composite stock price index in 2013 and 2015 (Figure 2.)

Many studies have examined the relationship between short-term portfolio investments and the rupiah exchange rate. Ibarra (2011) analyzed the influence of capital flows on the appreciation of RER in Mexico with ARDL bound test approach. The results found that the capital inflows caused peso to be appreciated between 1988 and 2008. The influx of foreign capital into the country from various forms, including; foreign debt, portfolio investment in the form of stocks and bonds, foreign trade surplus, and the others were effective on strengthening the domestic currency. Figure 3 illustrate the comparison between Rupiah Exchange Rate and IDX (Indonesian Composite Index) from 2010 to 2016. When the private debt experienced a drastic decline in the maturity of payments, the rupiah exchange rate would be depreciated, and vice versa.

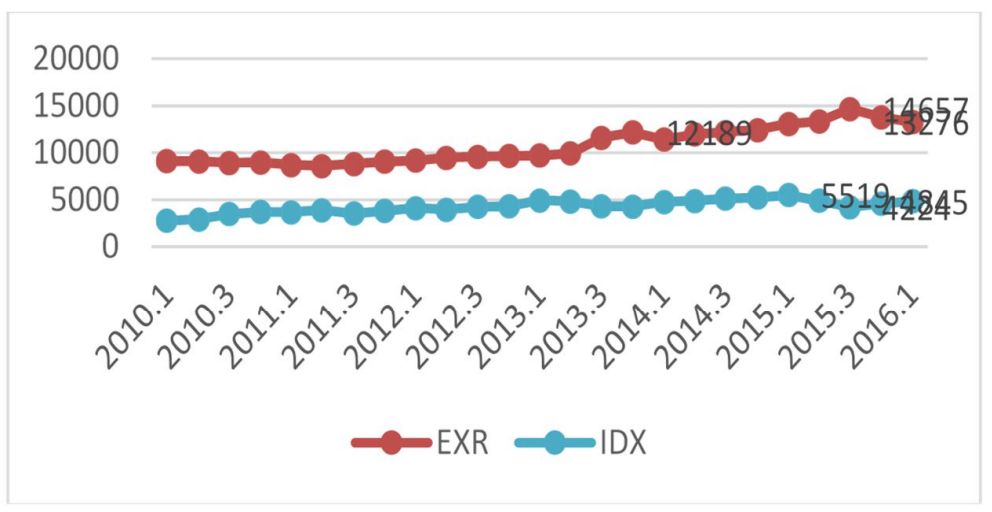

Source: Bank Indonesia, 2018

Figure 2. Rupiah Exchange Rate and IDX (Indonesian Composite Index) 


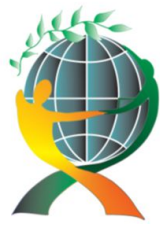

\author{
(online) $=$ ISSN $2285-3642$ \\ ISSN-L = $2285-3642$ \\ Journal of Economic Development, Environment and People \\ Volume 8, Issue 1, 2019
}

URL: http://jedep.spiruharet.ro

e-mail: office jedep@spiruharet.ro

Similarly, Uddin, Rahman, \& Quaosar (2014) also examined the factors influencing exchange rate fluctuations in Bangladesh with the co-integration approach. It was stated that macroeconomic variables influenced the Bangladesh currency in the end. The increase in debt, both private debt and government debt cause depreciation in the exchange rate, in contrast, a rise in foreign exchange reserves caused a currency appreciation. In addition, not only economics factors, but also social factors such as political issue had a negative impact on domestic exchange rate fluctuations.

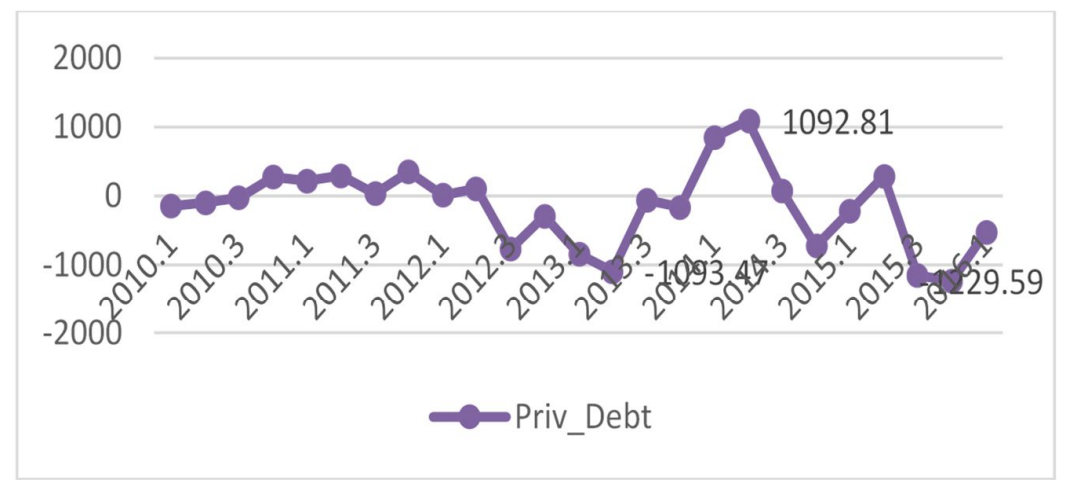

Source: Bank Indonesia, 2018

Figure 3. Short Term Private Debt Securities in Indonesia

In addition, the interest rate is also one of variables that is important in explaining the shock of the exchange rate. Foreign interest rates greatly affected the industrialized countries and eventually affected the economy of a country. Furthermore, the effectiveness of the influence of foreign interest rates was strongly influenced by the regime of the exchange rates adopted by a country (Giovanni \& Shambaugh, 2008).

Likewise, Wu \& Xia (2016) examined the effect of monetary variables on exchange rates in Asia-Pacific by using the Markov Switching Model (MSM). The Asia Pacific country used a varied exchange rate system and generally set its exchange rate with US dollars. After the 1997/1998 Asian crisis, the exchange rate was hard to be controlled so that the exchange rate tended to be volatile. The variables that determine the change in the exchange rate include money supply, discount rate, and industrial production.

Moreover, Elahi, Salimi, \& Masoomzadeh (2016) believed that the inflation Targeting Framework was very instrumental in maintaining the stability of exchange rates and trade balance in the countries. Some other fundamental variables greatly influence exchange rate fluctuations, such as gross domestic product, interest rate, money supply, and inflation.

Therefore, this paper aims to examine the effect of short-term portfolio investments and $\mathrm{BI}$ rate on exchange rates in Indonesia. It is remarkable to address this issue, as Indonesia is one of the countries with a highly volatile exchange rate where Indonesia is adopted free-floating exchange rate system. 


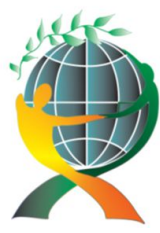

\author{
(online) $=$ ISSN $2285-3642$ \\ ISSN-L = $2285-3642$ \\ Journal of Economic Development, Environment and People \\ Volume 8, Issue 1, 2019
}

URL: http://jedep.spiruharet.ro

e-mail: office jedep@spiruharet.ro

\title{
2. Literature Review
}

\subsection{IS-LM Model}

In the IS-LM model, money supply and money demand are equal. On the supply side, M/P as the real money supply is equal to the demand that is the total number of transactions in the economy (Y). Demand for money, in this case, is strongly influenced by the interest rate. The interest rate is an opportunity cost for the choice of holding bonds or holding money. The change in interest rate is heavily influenced the investor's decision to make an investment (Blanchard, 2009)

$$
M / P=Y L(i)
$$

In the open financial markets, investors face the choice of whether to hold domestic or foreign assets. The choice is assumed that financial investors, both domestic and foreign, will choose an investment that will produce the highest expected rate of return. The difference in domestic and foreign interest rate greatly influences the investor's decision. The interest parity condition can be written (Blanchard, 2009):

$$
\left(1+\mathrm{i}_{\mathrm{t}}\right)=\left(1+\mathrm{i}_{\mathrm{t}}^{*}\right)\left(\frac{E t}{E_{t+1}^{e}}\right)
$$

Where $\mathrm{i}_{\mathrm{t}}^{*}$ is the foreign interest rate; $\mathrm{i}_{\mathrm{t}}$ is the domestic interest rate; $E_{t+1}^{e}$ is the future expected exchange rate; $E t$ is the real exchange rate. Hence, the real exchange rate can be written as:

$$
E t=\frac{1+i_{t}}{1+i_{t}^{*}} E_{t+1}^{e}
$$

This condition shows that domestic and foreign interest rates together with the expected exchange rate are strongly influenced the real exchange rate. Increasing in domestic interest rates will strengthen the exchange rate while rising in foreign interest rates will weaken the exchange rate. The expected exchange rate will also greatly affect the real exchange rate (Blanchard, 2009).

\section{Methodology}

This study uses a quarterly time series data of exchange rate, short-term private debt, BI Rate, and Composite Stock Price Index (IDX) from 2010 to 2016. The data are collected from Indonesia Central Bank. Auto-Regressive Distributed Lag (ARDL) bounds test method is being utilized to address the main objective issue. Pesaran \& Shin (1995) explained that the ARDL procedure have two steps. Firstly, it is to estimate the long-run relationships among the variables. Estimation can be performed using F-test that is the fundamental in assessing the long-run relationship. If the value of F-statistic is greater than the upper bound value, then the null hypothesis is rejected and can be concluded that there is no cointegration and, hence the long-run relationship runs among the variables. Meanwhile, if the value of the F-statistic is lower than the upper bound values, we do not reject the null hypothesis and assumed there is no long run relationship among variables. The second, it is to determine the coefficients of the long-run relationship. ARDL Model used in this study can be written as:

$$
\begin{aligned}
& \Delta E X R_{t}=\beta_{0}+\beta_{1} E X R_{t-1}+\beta_{2} I D X_{t-1}+\beta_{3} P R I V_{-} D E B T_{t-1}+\beta_{4} B I R A T E_{t-1}+\sum_{j=0}^{k} \gamma_{1 j} \Delta E X R_{t-j}+ \\
& \sum_{j=0}^{k} \gamma_{1 j} \Delta I D X_{t-j}+\sum_{j=0}^{k} \gamma_{2 j} \Delta P R I V_{-} D E B T_{t-j}+\sum_{j=0}^{k} \gamma_{3 j} \Delta B I R A T E_{t-j}+e_{1 t}
\end{aligned}
$$




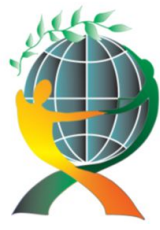

\author{
(online) $=$ ISSN $2285-3642$ \\ ISSN-L = 2285 - 3642 \\ Journal of Economic Development, Environment and People \\ Volume 8, Issue 1, 2019
}

URL: http://jedep.spiruharet.ro

e-mail: office jedep@spiruharet.ro

Where; EXR is the nominal exchange rate; PRIV_DEBT is short-term private debt; BIRATE is interest rate of Indonesia Central Bank that reflects the domestic interest rate; IDX is Composite Stock Price Index; $\beta_{0}$ is constant; $\beta_{1}-\beta_{4}$ are coefficient for short term; $\gamma_{1-} \gamma_{3}$ are coefficient for long term; $e_{1 t}$ is error term. In this study, Short Term Portfolio Investments were proxied with PRIV_DEBT (short-term private debt) and IDX is reflecting speculation activities in the capital market.

\title{
4. Results and Discussion
}

\subsection{Unit Root Test}

Shrestha \& Bhatta (2018) explains that if a value of time series data has a tendency to return to its average value in the long-run, and are not changed in time, then a data is called stationary. Nevertheless, if a value of time series data does not return to its average value in the long-run, then it is called nonstationary, which means that the variance and co-variance are not constant and changing over time. Many of the macroeconomic variables including inflation and exchange rate are not stationary. Gujarati (2009) said that if the estimation is conducted with the existence of unit root then the result of the estimation would be spurious regression. Spurious regression is defined as a regression that produces a biased conclusion that indicates the relationship of the variables is meaningless, for example, the $\mathrm{R}^{2}$ values would result in higher percentage even if the data is not correlated.

There are many types of unit root test included Augmented Dickey-Fuller (ADF), Phillips-Perron, KPSS, etc. Unlike other tests, the null hypothesis in KPSS test is trend stationary and the alternative hypothesis is non-stationary, which means that there is a presence of a unit root in the model (Naiya \& Abdul Manap, 2013).

From the results of the unit root test using KPSS-test, all variables used in this model are stationary. The exchange rate, the interest rate of the Indonesian central bank and private debt are stationary at first difference, I(1). On the other hand, the composite stock price index variable is stationary at level, I(0) (Table 1).

Table. 1. Unit Root Test

\begin{tabular}{ccccc}
\hline No & Variable & \multicolumn{3}{c}{ Kwiatkowski-Phillips-Schmidt-Shin (KPSS) } \\
& & LM Statistic \\
\cline { 2 - 5 } & At Level & 1st Difference & 2nd Difference \\
\hline 1 & EXR & - & $0.171192^{* *}$ & - \\
2 & IDX & $0.135394^{* * *}$ & - & - \\
3 & PRIV_DEBT & - & $0.500000^{* *}$ & - \\
4 & BIRATE & - & $0.125395^{* * *}$ & - \\
\hline$* *:$ Significant at 5 $\%, * * *:$ Significant at 10\% &
\end{tabular}

\subsection{Optimal Lag}

Iriobe, Obamuyi, \& Abayomi (2018) explained that before the ARDL bound test is conducted, the next step of ARDL model estimation step is to determine the optimal lag length of each variable by using Akaike's Information Criterion (AIC) or Schwarz Bayesian Criterion (SBC). Lag length is used as the basis for estimating short-term and long-term variables. In this study, we use the least Akaike's Information Criterion 


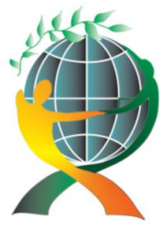

\author{
(online) $=$ ISSN $2285-3642$ \\ ISSN-L = $2285-3642$ \\ Journal of Economic Development, Environment and People \\ Volume 8, Issue 1, 2019
}

URL: http://jedep.spiruharet.ro

e-mail: office jedep@spiruharet.ro

(AIC) value to estimate the best-fitted ARDL model. From these results in Table 2, the selected ARDL model is in lag $(3,2,0,0)$.

Table 2. Estimation Result

Dependent Variable: D(EXR)

Model selection method: Akaike Information Criterion (AIC)

Selected Model: ARDL(1, 3, 0, 0)

\begin{tabular}{crrrr}
\hline \hline Variable & Coefficient & Std. Error & t-Statistic & Prob. $^{*}$ \\
\hline \hline D(EXR(-1)) & -0.261582 & 0.225610 & -1.159444 & 0.2657 \\
IDX & -0.598825 & 0.305901 & -1.957577 & 0.0705 \\
IDX(-1) & 0.366570 & 0.448893 & 0.816608 & 0.4278 \\
IDX(-2) & 1.119615 & 0.449617 & 2.490150 & 0.0260 \\
IDX(-3) & -0.654157 & 0.312236 & -2.095069 & 0.0548 \\
D(BI_RATE) & 209.7185 & 305.7607 & 0.685891 & 0.5040 \\
D(PRIV_DEBT) & 0.018577 & 0.153245 & 0.121227 & 0.9052 \\
C & -741.0033 & 745.3949 & -0.994108 & 0.3370 \\
\hline \hline R-squared & 0.671867 & & & \\
Adjusted R-squared & 0.507801 & & & \\
F-statistic & 4.095095 & & & \\
Durbin-Watson stat & 2.097973 & & & \\
\hline \hline
\end{tabular}

Table 2 describes that IDX is significantly affected the rupiah exchange rate at a confidence level of 5 to 10 percent. Meanwhile, other variables such as $\mathrm{BI}$ rate and short-term private debt do not significant affecting the exchange rate.

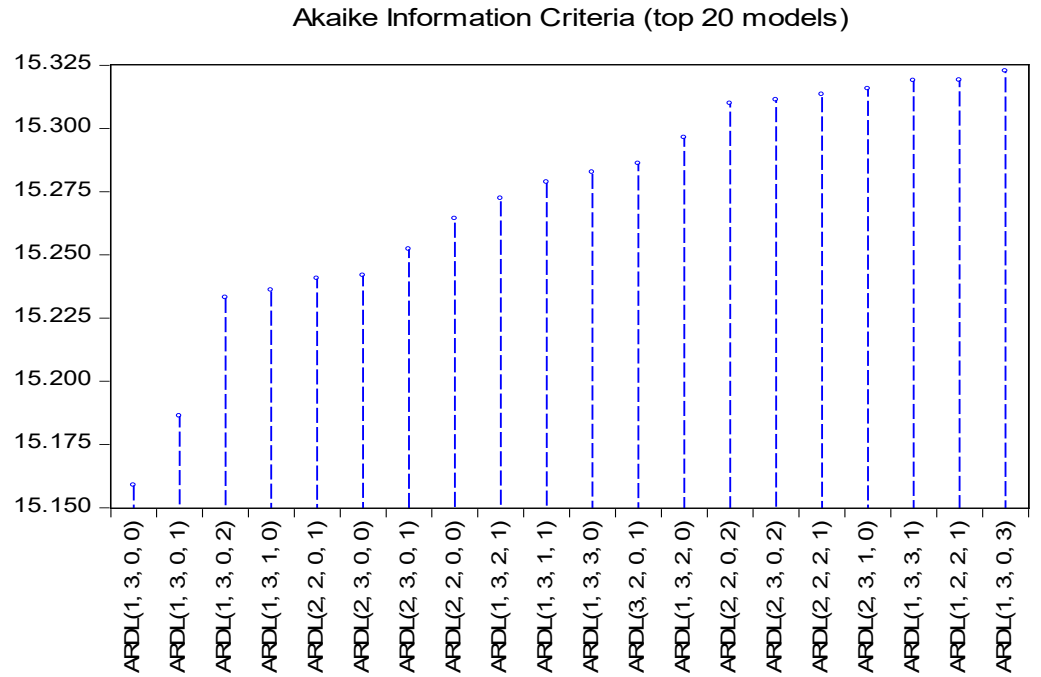

Figures 4. Lag Length Criterion 


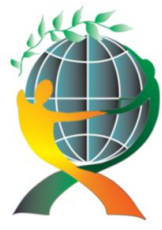

\author{
(online) $=$ ISSN $2285-3642$ \\ ISSN-L = $2285-3642$ \\ Journal of Economic Development, Environment and People \\ Volume 8, Issue 1, 2019
}

URL: http://jedep.spiruharet.ro

e-mail: office jedep@spiruharet.ro

Figure 4 shows the lag length criterion using AIC. There are 20 selected models, and the ARDL model in lag $(1,3,0,0)$ is the best fitted model used in this study. After that, the autocorrelation testing is done by looking at the residual test using the $\mathrm{Q}$ Colleogram table as shown in Table 3 below. From the results of the residual $\mathrm{UI}$, the $\mathrm{p}$-value is not significant at the confidence level of 5 to 10 percent, which means that the autocorrelation does not exist in this model.

Table 3. Residual Test

\begin{tabular}{|c|c|c|c|c|c|c|}
\hline Autocorrelation & Partial Correlation & & $A C$ & PAC & Q-Stat & Prob* \\
\hline$\cdot *|\cdot|$ & $\cdot{ }^{*}||$. & 1 & -0.068 & -0.068 & 0.1165 & 0.733 \\
\hline .1 .1 & .1 .1 & 2 & 0.025 & 0.020 & 0.1330 & 0.936 \\
\hline $.1 \cdot 1$ & $.1 \cdot 1$ & 3 & -0.057 & -0.054 & 0.2240 & 0.974 \\
\hline.$^{* *}|\cdot|$ &.$^{* *}|\cdot|$ & 4 & -0.281 & -0.292 & 2.5452 & 0.637 \\
\hline$\cdot 1^{*} \cdot 1$ & $\cdot I^{*} \cdot 1$ & 5 & 0.197 & 0.173 & 3.7487 & 0.586 \\
\hline $.1 \cdot 1$ & $.1 \cdot 1$ & 6 & -0.027 & 0.003 & 3.7731 & 0.707 \\
\hline$\cdot 1^{*} \cdot 1$ & .1 .1 & 7 & 0.113 & 0.072 & 4.2209 & 0.754 \\
\hline$\cdot * 1 \cdot 1$ & $\cdot *|\cdot|$ & 8 & -0.078 & -0.143 & 4.4532 & 0.814 \\
\hline$\cdot * 1 \cdot 1$ & .1 .1 & 9 & -0.066 & 0.029 & 4.6315 & 0.865 \\
\hline.$* *|\cdot|$ & $\cdot * *|\cdot|$ & 10 & -0.211 & -0.276 & 6.5861 & 0.764 \\
\hline$\cdot * 1.1$ & $\cdot * 1 \cdot 1$ & 11 & -0.121 & -0.101 & 7.2907 & 0.775 \\
\hline $.1^{*} \cdot 1$ & $.1^{*} \cdot \mid$ & 12 & 0.163 & 0.079 & 8.6954 & 0.729 \\
\hline$\cdot *|\cdot|$ & $\cdot{ }^{* *}|\cdot|$ & 13 & -0.195 & -0.220 & 10.921 & 0.617 \\
\hline$\cdot 1^{*} \cdot 1$ & $\cdot * 1 \cdot 1$ & 14 & 0.075 & -0.113 & 11.295 & 0.663 \\
\hline$\cdot *|\cdot|$ & $\cdot *|\cdot|$ & 15 & -0.121 & -0.090 & 12.391 & 0.649 \\
\hline$\cdot * 1 \cdot 1$ & $\cdot *|\cdot|$ & 16 & -0.147 & -0.127 & 14.282 & 0.578 \\
\hline$\cdot 1^{*} \cdot 1$ & .1 .1 & 17 & 0.149 & -0.019 & 16.630 & 0.480 \\
\hline .1 .1 & .1 .1 & 18 & -0.019 & 0.018 & 16.678 & 0.545 \\
\hline$\left.\cdot\right|^{*} \cdot \mid$ & .1 .1 & 19 & 0.185 & 0.059 & 22.722 & 0.250 \\
\hline .1 .1 & $\cdot *|\cdot|$ & 20 & 0.001 & -0.069 & 22.722 & 0.303 \\
\hline .1 .1 & $.1 \cdot 1$ & 21 & -0.017 & -0.019 & 22.880 & 0.350 \\
\hline
\end{tabular}

*Probabilities may not be valid for this equation specification.

\title{
4.3. Parameter Consistency Testing
}

Do \& Zhang (2016) checked the stability of coefficient using the cumulative sum of recursive residuals (CUSUM) and the CUSUM of square (CUSUMSQ), utilized by Pesaran \& Pesaran (1997). The plot of the CUSUM and CUSUM of squares describe about stability of coefficient and the long-run relationship among variables. If the line of CUSUM stays within the $5 \%$ significance bounds, then we do not reject the null hypothesis assumed that there is a long-run relationship among variables and thus shows stability of coefficient, and vice versa, if the plot of CUSUM exceed the $5 \%$, critical bounds then, the model is instable. With this result, plot of CUSUM in figure 5 do not exceed the $5 \%$ critical bounds, and hence we conclude that the coefficient in this model is stable and have long-run relationships among variables. 


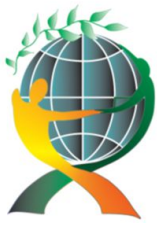

\author{
(online) $=$ ISSN $2285-3642$ \\ ISSN-L = $2285-3642$ \\ Journal of Economic Development, Environment and People \\ Volume 8, Issue 1, 2019
}

URL: http://jedep.spiruharet.ro

e-mail: office jedep@spiruharet.ro

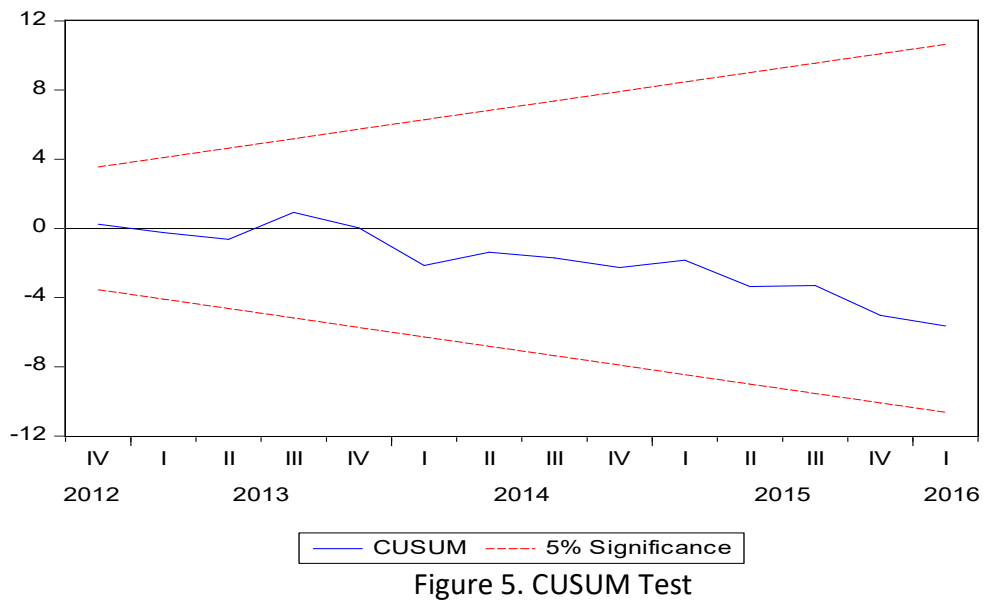

\title{
4.4. ARDL Bound Test
}

We used ARDL bounds test approach to investigate the long-term relationships between the variables, namely the relationship between the $\mathrm{BI}$ interest rate, short-term capital flows and fluctuations in the rupiah exchange rate. This is important to determine whether $\mathrm{BI}$ rate and changes in portfolio investments are significant in affecting the long-term exchange rate. We use F-test to examine this long-run relationship. Simultaneously, since the F-statistic value of 8.749687 is above the lower limit (I0) and upper limit (I1) of the Bounds test (Table 4), then we conclude that all variables used in this study are co-integrated. This means that $\mathrm{BI}$ rate is assumed to influence the rupiah exchange rate in the long term. In addition, shortterm fluctuations in capital flows, which are the joint stock price index and private debt securities also affect fluctuations in the rupiah exchange rate in the long run. This result is similar with Uddin, Rahman, \& Quaosar (2014) which concluded that both private debt and government debts are significant influencing the exchange rate in Bangladesh.

(Shakil, Mustapha, Tasnia, \& Saiti, 2018) explains that If long-term relationship occurs between the variables, the error-correction model (ECM) is conducted to estimate the balance that occurs between dependent and independent variables. A negative and significant of ECM value assists the information about the rate of speed adjustment of dependent variables returns to equilibrium after shock. A value of 1.261582 ( $p$-value $=0.0001$ ) assumed the speed of adjustments of the exchange rate to equilibrium the when there are changes in BI rate and short-term Portfolio Investments (Table 5). 


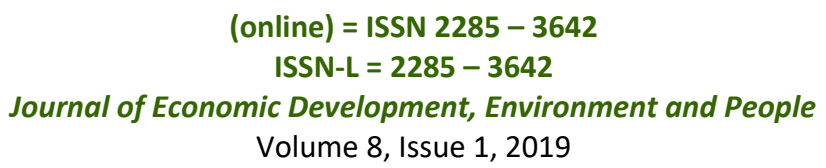

URL: http://jedep.spiruharet.ro

e-mail: office jedep@spiruharet.ro

Table 4. ARDL Bound Test

Null Hypothesis: No long-run relationships exist

\begin{tabular}{lll}
\hline \hline Test Statistic & Value & $\mathrm{K}$ \\
\hline \hline F-statistic & 8.749687 & 3 \\
\hline \hline Critical Value Bounds & \\
\hline \hline Significance & 10 Bound & 11 Bound \\
\hline \hline $10 \%$ & 2.72 & 3.77 \\
$5 \%$ & 3.23 & 4.35 \\
$2.5 \%$ & 3.69 & 4.89 \\
$1 \%$ & 4.29 & 5.61 \\
\hline \hline
\end{tabular}

Table 5. ARDL Cointegrating And Long Run Form Dependent Variable: $\mathrm{D}(\mathrm{EXR})$

\begin{tabular}{lllll}
\hline \hline Cointegrating Form & & & \\
\hline \hline Variable & Coefficient & Std. Error & t-Statistic & Prob. \\
\hline \hline D(IDX) & -0.598825 & 0.305901 & -1.957577 & 0.0705 \\
D(IDX(-1)) & -1.119615 & 0.449617 & -2.490150 & 0.0260 \\
D(IDX(-2)) & 0.654157 & 0.312236 & 2.095069 & 0.0548 \\
D(BIRATE, 2) & 209.718454 & 305.760721 & 0.685891 & 0.5040 \\
D(PRIV_DEBT, 2) & 0.018577 & 0.153245 & 0.121227 & 0.9052 \\
CointEq(-1) & -1.261582 & 0.225610 & -5.591876 & 0.0001 \\
\hline \hline Cointeq=D(EXR)-(0.1848*IDX+166.2345*D(BIRATE)+0.0147*D(PRIV_DEBT)-587.3604) & & \\
\hline \hline & Tabel 6. Long Run Coefficients & & \\
\hline \hline Variable & Coefficient & Std. Error & t-Statistic & Prob. \\
\hline \hline IDX & 0.184849 & 0.133077 & 1.389044 & 0.1865 \\
D(BI_RATE) & 166.234504 & 233.479025 & 0.711989 & 0.4882 \\
D(PRIV_DEBT) & 0.014726 & 0.121775 & 0.120924 & 0.9055 \\
C & -587.360406 & 593.158305 & -0.990225 & 0.3389 \\
\hline \hline
\end{tabular}




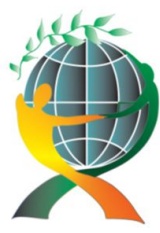

\author{
(online) $=$ ISSN $2285-3642$ \\ ISSN-L = $2285-3642$ \\ Journal of Economic Development, Environment and People \\ Volume 8, Issue 1, 2019 \\ URL: http://jedep.spiruharet.ro \\ e-mail: office jedep@spiruharet.ro
}

\title{
5. Conclusion and Recommendation
}

As an open economy country, Indonesia faces a problem regarding the volatility of the exchange rate. This paper investigates the influence of short-term portfolio and $\mathrm{BI}$ interest rate on rupiah exchange rate in Indonesia. We applied ARDL bound testing and CUSUM to investigate the long run and short run effect and test the stability of the model. The result of ARDL bound testing shows that Indonesia currency was strongly influenced by shocks in the private debt securities, joint stock price index, and BI Rate. Many studies support this finding, which stated that short-term portfolio investments and "Hot Money" because of speculation activities are very vulnerable causing fluctuations of exchange rate. Hence, it is suggested for the government to strengthen the stabilization of the short-term portfolio investments included private debt, capital flows, and to control the competitive interest rates. Moreover, many factors can be done to strengthen the rupiah exchange rate, including enhancing the trade surplus and strengthening domestic industries.

\section{References}

[1] Bank Indonesia. www.bi.go.id. 1512 2018. <www.bi.go.id>.

[2] Blanchard, Olivier. Macroeconomics, Fifth Edition. New Jersey: Pearson Education, Inc, 2009.

[3] Do, Thi Thao and Jian Hua Zhang. "ARDL Bounds Testing Approach to Cointegration: Relationship International Trade Policy Reform and Foreign Trade in Vietnam." International Journal of Economics and Finance 8.8 (2016): 84-94.

[4] Elahi, Naser, Farshid Salimi and Elahe Masoomzadeh. "Investigating Asymmetric Effects of Monetary Shocks on the Exchange Rate and Trade Balance, with an Emphasis on Inflation Targeting." Procedia Economics and Finance 36 (2016): 165-176.

[5] Giovanni, Julian di and Jay Shambaugh. "The impact of foreign interest rates on the economy: The role of the exchange rate regime." Journal of International Economics 74.2 (2008): 341-361.

[6] Gujarati, Damodar. Basic Econometric. New York: McGraw-Hill-Irwin, 2009.

[7] Ibarra, C. A. "Capital Flows and Real Exchange rate Appreciation in Mexico." World Development 39.12 (2011): 2080-2090.

[8] Iriobe, Grace O., Tomola M. Obamuyi and Muftau A. Abayomi. "Effect of Foreign Portfolio Investment in Bond Stocks on the Performance of the Nigerian Stock Market." Archives of Business Research 6.12 (2018): 164-172.

[9] Naiya, Ismaeel Ibrahim and Turkhan Ali Abdul Manap. "Structural Transformation, Poverty and Inequality in Nigeria: An ARDL Bound Testing Technique." International Journal of Economics and Finance 5.4 (2013): 141-152.

[10] Pesaran, H and B Pesaran. Microfit 4.0 Interactive Econometric Analysis. Oxford: Oxford University Press, 1997.

[11] Pesaran, M.H. and Y. Shin . "An Autoregressive Distributed Lag Modelling Approach to Cointegration Analysis." Cambridge Working Papers in Economics 9514, Faculty of Economics, University of Cambridge. (1995).

[12] Shakil, Mohammad Hassan, et al. "Is Gold a Hedge or a Safe Haven? An Application of ARDL Approach." Journal of Economics, Finance and Administrative Science 23.44 (2018): 60-76. 


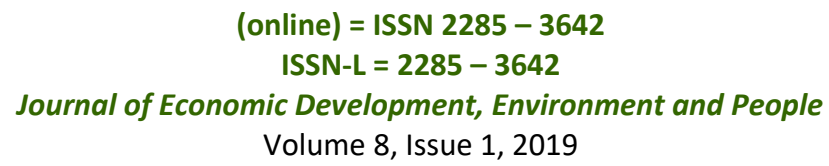

URL: http://jedep.spiruharet.ro

e-mail: office jedep@spiruharet.ro

[13] Shrestha, Min B. and Guna R. Bhatta. "Selecting Appropriate Methodological Framework for Time Series Data Analysis." The Journal of Finance and Data Science 4, 71-89. 4.2 (2018): 71-89.

[14] Uddin, Kazi Mohammed Kamal, Mohammad Morshedur Rahman and G. M. Azmal Ali Quaosar. "Causality Between Exchange Rate And Economic Growth In Bangladesh." European Scientific Journal 10.31 (2014): 11-26.

[15] Wu, Jing Cynthia and Fan Dora Xia. "Measuring the Macroeconomic Impact of Monetary Policy at the Zero Lower Bound." Journal of Money, Credit and Banking 48.2-3 (2016): 253-291. 